\title{
New concepts of pathogenesis in inflammatory bowel disease
}

\author{
Claudio FIOCCHI MD
}

C FIOCCHI. New concepts of pathogenesis in inflammatory bowel disease. Can J Gastroenterol 1995;9(5):261-270. The precise etiology and mechanisms of inflammatory bowel disease (IBD) are still unclear. Nevertheless, several concepts are gaining acceptance and constitute the basis for a better understanding of its pathogenesis and for improved therapy. The association of Crohn's disease (CD) and ulcerative colitis (UC) with 'western' lifestyle is well recognized, and is considered a reason for the increasing frequency of CD and UC in countries with previously low incidence. Proposed linkages of CD and UC with particular human leukocyte antigen haplotypes suggest a genetic predisposition, but no uniform or consistent patterns have emerged. Similarly, the study of susceptibility or disease markers has not offered reproducible results. The search for specific infectious agents is being pursued, and the measles virus is presently considered a possible culprit. A true explosion has occurred in the area of animal models, and a large number of chemically or genetically induced experimental colitides are at hand. Immunological factors continue to dominate the bulk of basic research in IBD. This area is vast and complex, and autoantibodies, immune, epithelial and mesenchymal cells, lipid mediators, cytokines, neuropeptides and oxygen metabolites are under investigation. Finally, other factors whose role in IBD is uncertain, including smoking and possible abnormalities of intestinal permeability or mucus composition, continue to receive attention. These extensive and varied efforts are yielding some profits, and new forms of therapy are being devised. Based mostly on studies of soluble mediators, a number of novel immunosuppressive and highly specific blocking agents are being developed and undergoing clinical trials.

Key Words: Animal models, Crohn's disease, Inflammatory bowel disease, Pathogenesis, Ulcerative colitis

\section{Nouveau concept dans la pathogenèse de la maladie inflammatoire de l'intestin}

RÉSUMÉ : L'étiologie précise des mécanismes de la maladie inflammatoire de l'intestin (MII) est encore mal définie. Néanmoins, plusieurs concepts sont de plus en plus acceptés et constituent la base d'une meilleure compréhension de sa pathogenèse et de l'amélioration des traitements. L'association de la maladie de

voir page suivante

Division of Gastroenterology, Case Western Reserve University, School of Medicine, Cleveland, Ohio, USA

Correspondence: Dr C Fiocchi, Division of Gastroenterology, Case Western Reserve University, School of Medicine, 10900 Euclid Avenue, Cleveland, OH 44106-4952, USA

This paper was presented at the Trends in Inflammatory Bowel Disease Therapy meeting, April 6 to 9, 1994, held in Victoria, British Columbia. This paper has also been published in Sutherland LR, et al, eds. Inflammatory Bowel Disease: Basic Research, Clinical Implications and Trends in Therapy. Boston, Dordrecht and London: Kluwer Academic Publishers, 1994
TNFlammatory BOWEL DISEASE

1 (IBD) continues to hold back many of the clues indispensable to reach a complete understanding of its etiology and pathogenesis. However, efforts directed at uncovering predisposing factors, identifying specific etiological agents, creating new animal models, investigating immunological abnormalities and developing novel and more effective forms of therapy continue to expand. Until the cause and mechanism(s) of IBD are clearly understood, many implicated factors will remain. To a large extent, this reflects limitations in knowledge, although there is general agreement that both Crohn's disease (CD) and ulcerative colitis (UC) are intricate multifactorial entities. Facing this discouraging complexity, an in-depth discussion of IBD pathogenesis can be quite extensive and diffuse. This laborious approach has already been taken, and comprehensive reviews are available $(1,2)$. This report focuses on selected and recent developments, particularly those having an impact on the pathophysiology of IBD.

\section{PREDISPOSING FACTORS}

Epidemiology: Epidemiological studies of IBD patients and their families have been carried out for a long time. The outcome of such studies has generated two essential pieces of information: a worldwide trend of an increased incidence of IBD - CD in particular-and the now well established notion of enhanced susceptibility to IBD among family members of CD or UC patients. Except for these important findings, the 
Crohn (MC) et de la colite ulcéreuse (CU) au mode de vie occidental est bien reconnue et explique en partie la fréquence accrue de $\mathrm{MC}$ et de $\mathrm{CU}$ dans des pays où elles étaient auparavant peu fréquentes. Les liens proposés entre MC ou CU et certains haplotypes antigéniques du leucocyte humain suggèrent une prédisposition génétique, mais aucun modèle uniforme ou cohérent n'a encore été établi. De même, l'étude de la sensibilité ou des marqueurs de la maladie n'a pas offert de résultats reproductibles. La recherche sur certains agents infectieux spécifiques se poursuit et le virus de la rougeole est à l'heure actuelle au banc des accusés. Une importante percée a été effectuée dans le domaine des modèles animaux et un grand nombre de colites expérimentales induites chimiquement ou génétiquement sont à notre disposition. Les facteurs immunologiques continuent de dominer la recherche fondamentale dans le domaine des MII. Cette voie d'exploration est vaste et complexe et les auto-anticorps, les cellules immunitaires, épithéliales et le mésenchyme, les médiateurs lipidiques, les cytokines, les neuropeptides et les métabolites de l'oxygène sont à l'étude. En dernier lieu, d'autres facteurs dont le rôle dans les MII est imprécis, y compris le tabagisme et de possibles anomalies de la perméabilité intestinale ou de la composition du mucus, continuent de recevoir une bonne part d'attention. Ces recherches approfondies et diversifiées portent fruits et de nouvelles formes de traitement sont mises au point. Principalement sur la base d'études sur les médiateurs solubles, un certain nombre de nouveaux agents exerçant un rôle d'immunosuppression et de blocage hautement spécifique sont en cours d'élaboration et font l'objet d'essais cliniques.

TABLE 1

Animal models of inflammatory bowel disease

\begin{tabular}{|c|c|c|c|}
\hline \multicolumn{2}{|c|}{ Exogenous induction } & \multicolumn{2}{|c|}{ Endogenous induction } \\
\hline Irritants & Ethanol, acetic acid & Spontaneous & $\begin{array}{l}\text { Cotton top tamarin, } \\
\text { C3H/HeJ mouse }\end{array}$ \\
\hline Drugs & $\begin{array}{l}\text { Nonsteroidal anti- } \\
\text { inflammatory drugs, } \\
\text { indomethacin }\end{array}$ & Clonal deletion & Cyclosporine A \\
\hline Immunological & $\begin{array}{l}\text { Immune complexes, trini- } \\
\text { trobenzene sulphonic } \\
\text { acid }\end{array}$ & $\begin{array}{l}\text { T cell reconstruc- } \\
\text { tion }\end{array}$ & $\begin{array}{l}\text { CD45RB }{ }^{\text {high }} \text { CD4 }+ \text { T cells in } \\
\text { severe combined immu- } \\
\text { nodeficiency mice }\end{array}$ \\
\hline $\begin{array}{l}\text { Bacterial prod- } \\
\text { ucts }\end{array}$ & $\begin{array}{l}\text { Peptidoglycan- } \\
\text { polysaccharide }\end{array}$ & Transgenic & $\begin{array}{l}\text { Human leukocyte antigen- } \\
\text { B27 }\end{array}$ \\
\hline Feeding & Dextran sulphate & Gene targeting & Interleukin-2, interleukin-10, \\
\hline $\begin{array}{l}\text { Nitric oxide- } \\
\text { related }\end{array}$ & Peroxynitrite & & $\begin{array}{l}\text { T cell receptor 'knockout' } \\
\text { mice }\end{array}$ \\
\hline Surgery & lleopouchitis & & \\
\hline
\end{tabular}

large number of population studies performed so far has not contributed much more to the critical question of whether IBD is predominantly a genetic disorder or is environmentally conditioned. A simple way of addressing this controversy is to put forward a classical multifactorial model, where many genes and multiple environmental influences determine the individual risk for developing IBD (3). But unless new clinical, familial or population clues surface, there is little chance that traditional epidemiology will contribute something new to IBD pathogenesis (4).
Immunogenetics: While classical epidemiology is practically at a standstill, significant progress is being made in the related field of immunogenetics. Following previous observations of an enhanced frequency of certain human leukocyte antigen (HLA)-DR haplotypes in selected and homogenous populations (5), new data support the possibility of distinct associations of HLA class II genes with IBD. Toyoda et al (6) recently reported a positive association of UC with the HLA-DR2 allele, and of CD with the HLA-DR1/DQW5 alleles (6). This endorses the long-held concept that the two forms of IBD are dis- tinct, and provides additional evidence for disease susceptibility and possible genetic heterogeneity. The latter concept is further strengthened by the observation that subgrouping of UC patients is possible when the HLA class II genes are analyzed in association with subclinical markers, such as antineutrophil cytoplasmic antibody (ANCA); ANCA-positive patients have an increased frequency of HLA-DR2 compared with ANCA-negative controls, whereas ANCA- negative patients have an increased frequency of HLA-DR4 compared with ANCA-positive patients (7).

Susceptibility markers: Detection of autoantibodies is a common finding in patients affected by chronic disorders with immune or inflammatory manifestations and in patients with IBD, in whom an association with numerous immune-related conditions has been long recognized. In addition to serum antibodies against gut epithelial antigens (8), the presence of a novel type of perinuclear ANCA (PANCA) has been reported (9). Antibody titres in the serum of UC patients are significantly higher than in patients with other colitides, leading to the suggestion that serum antibody titres represent a marker of this form of IBD (10). Furthermore, an increased PANCA prevalence was also found among healthy relatives in UC-affected families, making this autoantibody a potential marker of genetic susceptibility (11). Subsequent studies have generally supported these interesting observations, although the presence of additional autoantibodies in sera of UC patients has also been recently confirmed and associated with a generalized activation of the immune system in IBD (12).

\section{INFECTIOUS AGENTS}

Bacteria: The possibility that either form of IBD has a specific bacterial etiology has been considered since $\mathrm{CD}$ and UC were recognized as distinct clinical entities. Interest in searching for unique microorganisms has been wavering, but has never been abandoned. The approach taken to identifying new organisms has changed and become more sophisticated, but the quantity or 
quality of the results fall below what could be expected from more refined methodologies. Mimicking classical studies with serum antibodies, examination of immune cells from the general circulation or active IBD lesions has shown an augmented reactivity to a variety of bacterial antigens, but unique and selective responses have yet to be discovered $(13,14)$. The recent emphasis on a possible mycobacterial etiology of $\mathrm{CD}$ has spurred much interest and raised many hopes, but evidence that patients' peripheral or mucosal mononuclear cells mount a specific response against mycobacterial antigens is still missing (15). Reactivity of circulating T lymphocytes to the $65 \mathrm{kD}$ heat shock protein of mycobacterial origin is often detected, but this may simply reflect a nonspecific response shared by many chronic inflammatory and autoimmune disorders (16). Clustering of $\mathrm{CD}$ in families is a well described phenomenon, and this has been proposed as evidence of exposure of various family members to infectious microorganisms, but this is indirect and circumstantial at best (17).

Viruses: The most recent development in the area of causative microorganisms has been the demonstration that intestinal tissue of $\mathrm{CD}$ patients harbours persistent measles virus (18). The virus is located in endothelial cells that are part of granulomas, presumably leading to a vasculitis responsible not only for bowel inflammation but also the characteristic skip lesions of CD (19). This is a novel, exciting and intriguing hypothesis that deserves to be pursued.

\section{ANIMAL MODELS}

After decades of limited and occasional interest, the field of experimental colitis is experiencing a true explosion. In the past few years a substantial number of models in mice, rats, rabbits and immunodeficient animals have been developed and extensively tested (Table 1). The subject has been recently reviewed in detail (20), and it has been suggested that the sensible use of selected models can significantly contribute to our understanding of the pathogenesis of human IBD (21).

Exogenous induction: Among the models induced by administration of exogenous agents one of the most informative is the one where chronic colitis is initiated in rats by injecting the bowel wall with peptidoglycanpolysaccharide, a component of the cell membrane of certain bacteria (22). Particularly attractive features of this model are induction by naturally occurring substances that may be present in the gut lumen, formation of granulomas, accompanying systemic manifestations and, in particular, chronicity of inflammation that recurs in a biphasic fashion, suggesting a primary immune sensitization followed by a secondary response. This is a particularly attractive model also because of the observation that the rat strain has a major impact on the severity of colitis, suggesting an important contribution by genetic factors as proposed for humans (23). Another recently described model is one in which colitis appears in mice that have ingested dextran sulphate. An initial insult to the epithelial layer is followed by a secondary and chronic inflammatory infiltrate in the lamina propria (24). With the discovery of nitric oxide as a potential mediator of intestinal injury, new models centred on the production of nitric oxide in the intestinal wall have been very recently reported, although its exact role may vary from model to model $(25,26)$. Finally, the development of a model mimicking ileopouchitis in Lewis rats submitted to bowel reconstruction has been reported in preliminary form (27). Endogenous induction: In theory, a colitis model that does not require administration of a foreign substance may be a better model of IBD. Unfortunately the few spontaneous models, such as the south American cotton top tamarin or the $\mathrm{C} 3 \mathrm{H} / \mathrm{HeJ}$ mouse, have practical limitations. The newest way to create IBD models is to manipulate the immune system. A cyclosporine A-induced autoimmune disease in mature $\mathrm{T}$ cell-deprived mice shows striking inflammatory lesions in the colon but leaves the small bowel intact (28). This model reinforces the idea of how important autoimmune events are in the pathogenesis of IBD. A wasting syndrome associated with colo- nic inflammatory cell infiltration is induced in mice with severe combined immunodeficiency disease reconstituted with purified CD45RB high $\mathrm{CD} 4+\mathrm{T}$ cells, indicating that specific subsets of $\mathrm{T}$ helper cells may be critically important to bowel damage $(29,30)$.

At present, the most original models are those obtained by engineering the animal's genetic make up. In addition to the spontaneous bowel inflammation appearing in rats transfected with the human HLA-B27 allele (31), colitis or enterocolitis have been reported in mice undergoing gene-targeted disruption of the interleukin (IL)-2, IL-10 or $\mathrm{T}$ cell receptor (TCR) genes (32-34). As discussed by Strober and Ehrhardt (35), these 'knock out' animals suggest that chronic intestinal inflammation may arise from vastly different immune abnormalities, point to $T$ cells as primary culprits for inducing mucosal inflammation and stress how unique the intestine must be as a specific target of injury, considering that these animals lack the same gene products systemically (35). There is intriguing evidence that these animals do not develop colitis in a germ-free environment, but do so only if they harbour a normal lumenal content. If this is confirmed, the long-held suspicion that the interaction of enteric antigens with the local immune system is an indispensable condition to developing IBD may be finally proved.

\section{IMMUNOLOGICAL FACTORS}

Humoral immunity: The possibility that immune phenomena could be implicated in the pathogenesis of IBD was initially considered after the original demonstration that sera from UC patients could cross-react with colonic epithelial cells. From that pioneer observation demonstrating the existence of anticolon antibodies in IBD, a large number of studies have confirmed the presence of abnormalities in the production, type and class distribution of systemic and mucosal immunoglobulins ( $\mathrm{Ig}$ ) (36). Of particular interest are the changes in $\operatorname{IgG}$ distribution observed in the serum and mucosa of UC patients, where the predominance of IgG1 and the reduction of IgG2 sub- 
classes are found in patients and their monozygotic twins, which suggests at least a partial genetic contribution to those abnormalities (37). More interesting than the simple concentration or distribution of antibodies in UC or CD is the question of whether some of them are true autoantibodies, which would support a possible autoimmune nature of IBD (38).

Autoantibodies: The mere presence of self-reactive immunoglobulins, once considered the hallmark of autoimmune disease, no longer implies sickness but rather a phenomenon associated with ageing, or an epiphenomenon not relevant to tissue damage as seems to be the case for PANCA. However, if high titres of antibodies are consistently present and antibodies are located in, and specifically react with, an affected organ or tissue, then the possibility that they are responsible for immune-mediated injury should be seriously considered. As in many other conditions with immunological features, autoreactive antibodies have been described in IBD, but few have withstood the test of time and careful control studies.

At present only one putative autoantigen has been well characterized and shown to be reproducibly associated with high levels of specific autoantibodies. In a series of studies Das and collaborators (39) identified a tissuebound IgG that is eluted only from the colon of UC patients. After a $40 \mathrm{kD}$ protein reactive with such $\operatorname{IgG}$ was identified, a monoclonal antibody developed against this protein localized the antigen to the colon, skin and biliary epithelium. This striking distribution perfectly matches the localization of UC and the most common sites of the extraintestinal manifestations of this disease, lending further support to the notion that the $40 \mathrm{kD}$ protein could be the target of a true autoreactive response. Later the same investigators demonstrated that deposits of IgG and activated complement co-localize with the $40 \mathrm{kD}$ protein in UC colon, suggesting a possible mechanism of tissue destruction (40). Further developments include the preliminary characterization of the autoantigen as a $\mathrm{P} 40$ protein belonging to the tropomyosin family, a group of common structural proteins, and the detection of antibodies reactive to tropomyosin in $95 \%$ of sera from patents with UC (41). Finally, most sera of patents with primary sclerosing cholangitis can block binding of the monoclonal antibody in an inhibition assay using sections of bile ducts or gallbladder (42). This indicates that patients with primary sclerosing cholangitis have circulating antibodies able to bind to an epitope of the peptide shared by biliary and colonic epithelium, further strengthening the possibility of autoimmunity in UC pathogenesis. However, whether a tropomyosin is the primary target of an immune response in UC and whether antibodies directed against it have real pathogenic potential still remain to be conclusively established.

\section{CELLULAR IMMUNITY}

Investigation of the type, distribution and function of the immune cells in the systemic circulation and intestine of IBD patients has been a major focus for many years. For well over a decade this attention has gradually shifted from the peripheral circulation to the gut mucosa. Initially, only classical immune cells, such as T and B lymphocytes, were examined until it became evident that other types of local cells exhibited similar properties and secreted the same products as those of mononuclear cells. Thus, the idea that cell-mediated immunity in the normal and diseased mucosa is solely mediated by 'immune' cells is no longer acceptable, and a whole new set of 'nonimmune' cells must be taken into account, substantially enhancing the complexity of assessing IBD immunopathophysiology.

Epithelial cells: One of the best examples of 'nonimmune' cells playing a role in IBD is that of epithelial cells. These cells express HLA class II antigens on the cell surface, a condition indispensable for antigen presentation and accessory cell function. In the inflamed intestine expression of class II antigens is enhanced, suggesting an involvement of epithelial cells in the local immune response. Mostly based on the work of Mayer and colleagues (43) it is now accepted that these cells regulate intestinal immunity in health and disease. The most prominent observations were the ability of epithelial cells to present antigens and the abnormality of this function in IBD, where helper $\mathrm{T}$ cells rather than suppressor cells are preferentially activated by $\mathrm{CD}$ or $\mathrm{UC}$ epithelial cells (43). This could be a mechanism for expanding or perpetuating an undesirable and excessive immune reactivity in the gut. Other investigators have extended these observations, showing evidence that drugs beneficial to IBD patients can downregulate HLA-DR antigens on epithelial cells $(44,45)$.

Intraepithelial lymphocytes and lamina propria mononuclear cells: The intestinal mucosa is populated by a rich and extremely varied number of cells (46). Knowledge of the population of intraepithelial lymphocytes in IBD is still rather limited, but a few interesting observations have been made. As in the normal intestine, the majority of intraepithelial lymphocytes display a dominant $\mathrm{CD} 3+\mathrm{CD} 8+$ phenotype, but the proportion bearing the $\gamma \delta$ TCR $(\mathrm{TCR} \gamma \delta+)$ is decreased in $\mathrm{CD}$ and, even more remarkably, in UC $(47,48)$. The normal population of human intraepithelial lymphocytes tends to display a restricted set of $V_{\beta}$ regions for its TCR, suggesting oligoclonality (49), and this may also occur in IBD (50).

In the lamina propria $T$ cells are second in number only to plasma cells, attesting to their fundamental importance in local regulatory and effector functions. There is strong evidence that $\mathrm{T}$ cells play a major role in the morphological changes associated with tissue damage. In situ activation of lamina propria $T$ cells results in injury to the mucosa, and there is a quantitative relationship between the number of $\mathrm{T}$ cells and the degree of tissue destruction (51). T lymphocytes have been evaluated extensively in control and IBD intestine, but no consistent shift of CD4+ or CD8+ subsets has been found. However, as in the intraepithelial compartment, the number carrying the TCR $\gamma \delta$ is decreased (47).

Obviously during a pathological re- 
action many factors contribute to the final outcome of local immune response, but even in the normal mucosa there is evidence that the activation pathways most commonly used by local cells differ from those of circulating cells, a phenomenon that may depend on the unique make up of the mucosal microenvironment (52). Whether the IBD microenvironment is fundamentally different from that of the normal gut is being assessed. A possibility being investigated is that endogenous or exogenous superantigens may be present and induce the activation of specific types of mucosal T cells. Evidence supporting this possibility exists (53), but a firm link to selective use of a restricted set of $\mathrm{V}_{\beta}$ regions in IBD mucosa is still lacking $(54,55)$ even though some preliminary reports suggest this possibility (56). Nevertheless, IBD may still be similar to other autoimmune conditions associated with depletion or overrepresentation of certain T cells with a unique TCR $\mathrm{V}_{\beta}$ region use (57), and this needs to be explored in detail.

Other immune cells continue to receive little attention, but this should not be interpreted as a sign that they are not important to IBD pathogenesis. Rather, this reflects a technical problem in isolating or working with such cells that are often few in number. A general impression is that all of them tend to be activated and release bioactive mediators $(58,59)$.

Mesenchymal cells: Once considered simple structural cells, fibroblasts and muscle cells are now recognized as metabolically active and biologically important in overall gut homeostasis. Both cell types have shed the image of nonimmune bystanders and must be included in the realm of immunologically active cells. Although morphologically similar, mesenchymal cells from different parts of the body have unique functional characteristics, as demonstrated by colonic fibroblasts' capacity to produce collagen rather than skin fibroblasts (60). During inflammation, especially when chronic as in IBD, gut mesenchymal cells change both phenotypically as well as functionally $(61,62)$, a phenomenon likely to depend on the inflammatory reaction in their proximity. Despite these changes being secondary, the importance of mesenchymal cells does not diminish. In fact, pathological findings typical of UC or CD, such as shortening of the bowel and stricture formation, are due to the effect of excessive collagen deposition and muscle cells hyperplasia. Recent data demonstrate enhanced collagen production by fibroblasts in tissue culture, by immunohistochemistry and in situ hybridization. Furthermore, the spectrum of functional responses and modulatory activity of mesenchymal cells is certainly broader than originally thought in view of these cells' capacity for proliferating in response to, and generating mRNA for, a variety of proinflammatory cytokines, including IL-1, IL -6 and tumour necrosis factor (TNF) $-\alpha$ (63).

Cell adhesion molecules: With the expanding number of known mucosal cell types that actively participate in the IBD reaction, and the multiple interactions occurring among them, one may assume that some mechanisms must be in place to allow or facilitate such intricate interplay. The obvious candidates for this complex and important function are adhesion molecules, a large group of cell surface proteins that allow contact, physical attachment and biological interaction between two or more cell types (64). The role of adhesion molecules becomes even more important in inflammation, and they can be pivotal to the outcome of any inflammatory response given their ability to control cell to cell contact, as well as the entry and exit of inflammatory cells from tissues (65). Evidence that adhesion molecules have an important role in IBD pathogenesis is accumulating. Although expression of the leukocyte adhesion molecules CD11/CD18 is not increased in circulating cells (66), an entirely different situation exists in actively inflamed gut. The percentage of tissue macrophages expressing leukocyte function-associated antigen-1, CD11A, is strikingly increased in both UC and CD mucosa, and correlates with severity of inflammation (67). High levels of endothelial leukocyte adhesion molecule-1, but not vascular cell adhesion molecule-1, are detected in actively inflamed areas of $\mathrm{CD}$ or UC $(68,69)$, in addition to an increase of intracellular adhesion molecule-1 and Eand $\mathrm{P}$-selectins in venules and very late activation antigen (VLA)-4 on mononuclear cells (70). The enhanced expression of several adhesion molecules can be functionally translated into an abnormal function of peripheral and intestinal mononuclear cells in IBD: blood cells show an enhanced tendency to form granulomas in vitro (71) and lamina propria lymphocytes lose selectivity in their interaction with high endothelial venules (72). Finally, considering how important adhesion molecules are in controlling the number and type of cells in inflammatory infiltrates, blockade of adhesion molecule expression may result in modulation of inflammation. Preliminary evidence supporting this possibility has been recently reported in the cotton top tamarin, where the administration of anti-VLA-4 monoclonal antibody results in significant attenuation of acute colitis (73).

Soluble mediators: Among the numerous components of the immune and inflammatory reaction of IBD none have received as much attention as soluble mediators. 'Soluble mediators' is a broad term including any molecule produced by activated cells and released in the immediate vicinity, such as eicosanoids, growth factors and cytokines. The unparalleled interest in cytokines is explained by their extremely broad and potent activity on almost every aspect of pathophysiology in development, immunity and inflammation, and their potential for providing unprecedented insights into mechanisms of disease and novel therapeutic approaches (74).

Lipid mediators: The enhanced production of eicosanoids (prostanoids and leukotrienes) in IBD mucosa was one of the first findings demonstrating that inflammatory cells secrete bioactive substances at the level of the diseased mucosa, and implicating, for the first time, soluble mediators in the pathogenesis of UC and CD. This concept has become well established, and until recently inflammatory cells were consid- 
ered solely responsible for the enhanced production of prostaglandins, thromboxanes and leukotrienes. This concept has changed rather dramatically in the past few years with the demonstration that other cell types also play an active role in local eicosanoid metabolism. The most novel finding is clear proof that epithelial cells are involved in this process, and produce lipid mediators even under normal circumstances. At active sites of inflammation these cells produce significantly increased amounts of platelet-activating factor and 12 lipoxygenase $(75,76)$. These are important observations because they expand the number of cells involved in inflammation and, in particular, broaden the spectrum of activities of epithelial cells in the local immune response.

Cytokines: The field of intestinal cytokines in normal and abnormal mucosal immunity is experiencing a true explosion of interest and knowledge. Unfortunately this positive trend is complicated in IBD by conflicting reports on the levels of cytokines in the serum, culture supernatants or intestinal tissues of CD and UC patients. This confusing situation is due, at least in part, to the use of vastly different methodological approaches (stimulated versus unstimulated conditions, bioassays versus immunoassays, mRNA assessment by immunoblotting or polymerase chain reaction, etc) and different patient populations (adult versus pediatric, acute versus chronic, on versus off medication, etc). Several excellent and comprehensive reviews provide an indepth evaluation of this subject (77$80)$. The scope of this article is limited to only the most recent and salient developments.

Of the several immunoregulatory cytokines (IL-2, IL-4, IL-5, IL-10 and interferon [IFN]- $\gamma$ ) IL-2 probably has a direct role in the pathogenesis of CD. In spite of contradictory results on its levels under experimental conditions, patients with $\mathrm{CD}$ receiving treatment with high doses of this cytokine for cancer immunotherapy experience symptomatic exacerbations (81). In contrast, patients with active disease who develop AIDS and loss of IL-2-producing CD4+ T cells enter remission (82). The genes for IL-2 and its receptor (IL-2R) are usually expressed at a higher degree in $\mathrm{CD}$ than in UC patients $(83,84)$, and so are its products including the soluble form of the IL-2R whose circulating levels roughly reflect the severity of immune activation in CD but not UC mucosa (85).

The production of the so-called proinflammatory cytokines (IL-1, IL-6, IL-8 and TNF- $\alpha$ ) is almost invariably increased, although results from different investigators are not always uniform. All agree that the production of IL-1 in IBD tissue is markedly and consistently elevated during active disease. Much of the interest related to this potent proinflammatory substance is now centred on its antagonist, the IL-1 receptor antagonist (IL-1RA), a natural protein that blocks the receptor for IL-1 without triggering an inflammatory response (86). Two points deserve special attention: more than the levels of IL-1, the most important factor in determining how much inflammatory activity will ensue may actually depend on the relative concentration of IL-1RA and IL-1, the IL-1RA:IL-1 ratio. Evidence indicates that a mucosal imbalance between these two molecules is present in IBD, and this may lead to chronic inflammation (87). In addition, genetic polymorphism for the allelic frequencies of IL-1RA may be another factor predisposing to UC or a more severe form of it (88).

The production, cellular source and overall role of TNF- $\alpha$ in IBD continues to be quite controversial but, except for one group of studies, this cytokine does not appear to be produced in exceedingly large amounts as predicted by the severity of inflammation in CD or UC, or other form of gut injury $(89,90)$. The potent proinflammatory mediator IL-8, which is primarily a chemotactic agent for neutrophils, is also receiving attention in IBD. Gut tissue actively involved in $\mathrm{UC}$ or $\mathrm{CD}$ contains extremely elevated levels of this chemokine, even though circulating antibodies IL-8 in the peripheral blood are only found in UC (91-93). A novel and interesting aspect of IL-8 is its apparent production by gut epithelial cells, reinforcing the idea that these cells are indeed involved in gut inflammation (94).

Growth factors: Growth factors represent a large group of peptides produced by multiple cell types, and they affect the growth and differentiation of epithelial cells. There is strong evidence that these peptides are involved in various stages of the IBD process (80). Some, such as insulin growth factor-I, have been implicated in the pathogenesis of experimental colitis and hepatitis in rats (95), indicating that growth factors are broadly involved in any inflammatory response of the gastrointestinal tract. The expression of some of these factors, such as trefoil peptides associated with gut ulceration and the angiogenic peptide basic fibroblast growth factor, is enhanced in IBD $(96,97)$. Growth factors in general, and transforming growth factor (TGF) $\beta 1$ in particular, are likely to be involved in the healing process accompanying intestinal inflammation, a function that can be co-modulated by other growth factors (TGF $\alpha$ and epidermal growth factor) and cytokines (IL-10 and IFN-7) $(98,99)$.

Neuropeptides: The existence of a 'brain-gut axis' has been long suspected, but until recently this concept was based more on intuition and clinical impression than on concrete scientific evidence. With the demonstration of how rich the enteric nervous system is, and how intimate the relationship between nerve fibres and immune cells is, the basis for the brain-gut axis gained considerable support (100). In addition, well defined physical and biochemical pathways linking the stress response to the regulation of inflammatory diseases have been established (101), providing additional backing for the clinical observation that stress can induce a clinical flare-up in IBD patients. Evidence is now unquestionable that the enteric nervous system has a definitive role in regulating the function of both humoral and cellular gut immunity. This function is mediated through the secretion of a large number of neuropeptides, or 'cytokine equivalents', for the nervous cells. These are located close to T and B cells, macrophages, mast cells, etc, and during in- 
flammation nerve cells surprisingly express HLA-DR antigens to an extent correlating to that of epithelial cells (102). Thus, the role of enteric nerves and their interaction with local immunocytes is much more extensive and important than previously noted. For instance, a recent report shows how vasoactive intestinal peptide (VIP) markedly upregulates $\operatorname{IgA}$ and downregulates IgG production by human colonic lamina propria mononuclear cells in vitro (103). The function of VIP and other neural substances is likely to be much more extensive, and future work will define the impact of enteric neuropeptides on mucosal immunity.

Oxygen metabolites: Reactive oxygen metabolites (ROM) do not fit the same definition of soluble mediators used for the above substances because they do not circulate and their existence is transient. Nevertheless, they represent another kind of secretory product of activated inflammatory cells (104) because they are highly cytotoxic to a variety of cells in vitro and in vivo. There is abundant evidence that large amounts of ROM are produced in IBD by various types of mucosal cells (105, 106). In addition to the gut, circulating monocytes from IBD patients can release ROM, a phenomenon that can be triggered by bacterial products (107). Oxygen metabolites have been proposed as a possible final pathway of injury for many of the immune and nonimmune events occurring in the inflamed bowel of humans and animals $(108,109)$. This concept is supported by studies showing a beneficial effect of oxygen radical scavengers in IBD (110).

\section{MISCELLANEOUS FACTORS}

A feature common to many complex and chronic conditions is the proposed multifactorial origin, where the cumulative effect of several factors results in the triggering or modulation of the disease. Perhaps no better example of this exists than in IBD, in which a number of observations have been made regarding various factors or conditions for which there is limited scientific evidence or logical explanation.

Smoking: The initial studies describing the effect of smoking on the clinical course of $\mathrm{CD}$ or $\mathrm{UC}$ were received with scepticism. However, when reports from various centres started accumulating it became impossible to dismiss data showing a beneficial effect of smoking in UC and a detrimental effect in CD $(111,112)$. This dichotomy is exceedingly puzzling, but the findings are so consistent and reproducible that the effect of smoking may actually reflect some event fundamentally linked to the etiopathogenesis of both forms of IBD (113). The mechanism by which smoking may modulate the clinical manifestations of IBD is just as perplexing and enigmatic, and not surprisingly nicotine has been blamed, despite that there is no obvious evidence implicating this alkaloid. However, a study just published shows that the addition of transdermal nicotine to conventional treatment significantly improves symptoms in UC patients (114).

Intestinal permeability: The finding of an increased intestinal permeability in $\mathrm{CD}$ patients is not surprising, but the suggested existence of a similar defect in healthy relatives has raised substantial interest in it as a potential predisposing factor. This observation has attracted considerable attention, but results have been controversial, with some reports reinforcing and others denying the existence of altered intestinal permeability in unaffected relatives of CD subjects (115-117). In one study, increased permeability was even detected in the lungs of $C D$ patients (117). The key question regarding these curious observations is whether a permeability defect is a primary etiological factor or is secondary to intestinal inflammation (118). This is not an easy question to address, but careful studies have identified at least a subset of healthy relatives with high permeability in the absence of obvious clinical evidence of disease (119). The arduous aspect of this problem is how to define 'absence of disease' precisely, because very early defects of epithelial structure and function may be so subtle as to be undetectable by routine methods and thus go unno- ticed. Until better methods to evaluate permeability or define normality of absorptive mechanisms are developed, the question of increased intestinal permeability in $\mathrm{CD}$ is likely to remain.

\section{SUMMARY AND CONCLUSIONS}

The ultimate goal of fully understanding the pathogenesis of IBD is to help patients by developing scientifically based, truly efficacious treatments that have high specificity and are free from side effects. Although not quite at hand, realizing this goal appears feasible based on the rapidly accumulating knowledge of the various immunopathogenic components of IBD. Many of the new therapies now undergoing clinical trials are based on this approach (120). The strongest emphasis is to create new interventions based on an understanding of inflammatory mediators (121); this has resulted in therapies varying from administering injections of IL-1RA to simple dietary manipulations (122). The drugs that both clinicians and patients have relied upon for years are being given new names, new appearances and heightened cost, but it remains to be proven whether this has really improved their effectiveness (123). A new series of immunosuppressive drugs are being tested, but most suffer the same disadvantages as the old ones, ie, lack of specificity, toxicity and side effects (124). Finally, not all that is new and better must carry the lustre and respect of the laboratory bench. Clinical observation is still a centrepiece of medical care and can still be used to improve or change therapy. A good example of this is the use of short chain fatty acid or butyrate enemas for UC, apparently with promising results $(125,126)$. Solid scientific evidence for a long held 'energy deficient state' in UC is still limited (127), but common sense and intuition may go a long way.

\section{REFERENCES}

1. Fiocchi C. Pathophysiology: facts, hopes and implications for treatment. In: Scholmerich J, Kruis W, Goebell H, Hohenberger W, Gross V, eds. Inflammatory Bowel Disease:

Pathophysiology as Basis of Treatment. 
Lancaster: Kluwer Academic Publishers, 1993:257-9.

2. Shanahan F. Pathogenesis of ulcerative colitis. Lancet 1993;342:407-11.

3. Sofaer J. Crohn's disease: the genetic contribution. Gut 1993;34:869-71.

4. Lashner BA, Kirsner JB. The epidemiology of inflammatory bowel disease: are we learning anything new? Gastroenterology 1992;103:696-8.

5. Asakura H, Tsuchiya M, Aiso S, et al. Association of the human lymphocyteDR2 antigen with Japanese ulcerative colitis. Gastroenterology 1982;82:413-8.

6. Toyoda H, Wang S-J, Yang H-J, et al. Distinct associations of HLA class II genes with inflammatory bowel disease. Gastroenterology 1993;104:741-8.

7. Yang H, Rotter JI, Toyoda H, et al. Ulcerative colitis: a genetically heterogenous disorder defined by genetic (HLA class II) and subclinical (antineutrophil cytoplasmic antibodies) markers. J Clin Invest 1993;92:1080-4.

8. Fiocchi C, Roche JK, Michener WM. High prevalence of antibodies to intestinal epithelial antigens in patients with inflammatory bowel disease and their relatives. Ann Intern Med 1989;110:786-94.

9. Saxon A, Shanahan F, Landers C, Ganz T, Targan S. A distinct subset of antineutrophil cytoplasmic antibodies is associated with inflammatory bowel disease. J Allergy Clin Immunol 1990;86:202-10.

10. Duerr RH, Targan SR, Landers CJ, Sutherland LR, Shanahan F. Anti-neutrophil cytoplasmic antibodies in ulcerative colitis. Comparison with other colitides/diarrheal diseases. Gastroenterology 1991;100:1590-6.

11. Shanahan F, Duerr RH, Rotter JI, et al. Neutrophil autoantibodies in ulcerative colitis: familial aggregation and genetic heterogeneity. Gastroenterology 1992;103:456-61.

12. Dalekos GN, Manoussakis MN, Goussia AC, Tsianos EV, Moutsopoulos HM. Soluble interleukin-2 receptors, antineutrophil cytoplasmic antibodies, and other autoantibodies in patients with ulcerative colitis. Gut 1993;34:658-64.

13. Fiocchi C, Battisto JR, Farmer RG. Studies on isolated gut mucosal lymphocytes in inflammatory bowel disease. Detection of activated T cells and enhanced proliferation to Staphylococcus aureus and lipopolysaccharides. Dig Dis Sci 1981;26:728-36.

14. Pirzer U, Schonhaar A, Fleischer B, Hermann E, Buschenfelde K-HM. Reactivity of infiltrating T lymphocytes with microbial antigens in Crohn's disease. Lancet 1991;338:1238-9.

15. Ibbotson JP, Lowes JR, Chahal H, et al. Mucosal cell-mediated immunity to mycobacterial, enterobacterial and other microbial antigens in inflammatory bowel disease. Clin Exp Immunol 1992;87:224-30.

16. Szewczuk MR, Depew WT. Evidence for T lymphocyte reactivity to the 65 kilodalton heat shock protein of mycobacterium in active Crohn's disease. Clin Invest Med 1992:15:494-505.

17. Kruiningen HJV, Colombel JF, Cartun RW, et al. An in-depth study of Crohn's disease in two French families. Gastroenterology 1993;104:351-60.

18. Wakefield AJ, Pittilo RM, Sim R, et al. Evidence of persistent measles virus infection in Crohn's disease. J Med Virol 1993;39:345-53.

19. Wakefield AJ, Sawyerr AM, Hudson M, Dhillon AP, Pounder RE. Smoking, the oral contraceptive pill, and Crohn's disease. Dig Dis Sci 1991;36:1147-50.

20. Stenson WF. Animal models of inflammatory bowel disease. In: Targan SR, Shanahan F, eds. Inflammatory Bowel Disease. From Bench to Bedside. Baltimore: Williams \& Wilkins, 1994:180-92.

21. Fiocchi C. Cytokines and animal models: a combined path to inflammatory bowel disease pathogenesis. Gastroenterology 1993;104:1202-19.

22. Yamada T, Sartor RB, Marshall S, Specian RD, Grisham MB. Mucosal injury and inflammation in a model of chronic granulomatous colitis in rats. Gastroenterology 1993;104:759-71.

23. McCall RD, Haskill S, Zimmermann EM, Lund PK, Thompson CR, Sartor RB. Tissue interleukin-1 and interleukin-1 receptor antagonist expression in enterocolitis in resistant and susceptible rats. Gastroenterology 1994;106:960-72.

24. Cooper HS, Murthy SNS, Shah RS, Sedergran DJ. Clinicopathologic study of dextran sulphate sodium experimental murine colitis. Lab Invest 1993;69:238-49.

25. Caplan MS, Hedlund E, Hill N, MacKendrick W. The role of endogenous nitric oxide and platelet-activating factor in hypoxia-induced intestinal injury in rats. Gastroenterology 1994:106:346-52

26. Rachmilewitz D, Stamler JS, Karmeli F, et al. Peroxynitrite-induced rat colitis - A new model of colonic inflammation. Gastroenterology 1994;105:1681-8.

27. Lacey SR, Lichtman S. Development of an animal model for ileoanal pouchitis. J Ped Surgery 1993;28:574-5.

28. Bucy RP, Xu XY, Li J, Huang GQ. Cyclosporine $\mathrm{A}$-induced autoimmune disease in mice. J Immunol 1993;154:1039-50.

29. Powrie F, Leach MW, Mauze S, Cadde LB, Coffman RL. Phenotypically distinct subsets of CD4+ T cells induce or protect from chronic intestinal inflammation in C B-17 scid mice. Int Immunol 1993;5:1461-71.

30. Morrisey PJ, Charrier K, Braddy S, Liggit D, Watson JD. CD4+ T cells that express high levels of CD45RB induce wasting disease when transferred into congenic severe combined immunodeficient mice. Disease development is prevented by cotransfer of purified CD4+ T cells. J Exp Med 1993;178:237-44.

31. Hammer RE, Maika SD, Richardson JA, Tang J-P, Taurog JD. Spontaneous inflammatory disease in transgenic rats expressing HLA-B27 and human $\mathrm{b} 2 \mathrm{~m}$ : an animal model of HLA-B27-associated human disorders. Cell 1990;63:1099-112.

32. Sadlack B, Mertz H, Schorle H, Schimpl A, Feller AC, Horak I. Ulcerative colitis-like disease in mice with a disrupted interleukin-2 gene. Cell 1993;75:253-61

33. Kuhn R, Lohler J, Rennick D, Rajewsky $\mathrm{K}$, Muller W. Interleukin-10-deficient mice develop chronic enterocolitis. Cell 1993;75:263-74

34. Mombaerts P, Mizoguchi E, Grusby MG, Glimcher LH, Bhan AK, Tonegawa S. Spontaneous development of inflammatory bowel disease in $\mathrm{T}$ cell receptor mutant mice. Cell 1993;75:275-82.

35. Strober W, Ehrhardt RO. Chronic intestinal inflammation: an unexpected outcome in cytokine or $\mathrm{T}$ cell receptor mutant mice. Cell 1993;75:203-5.

36. Brandtzaeg P, Halstensen TS, Kett K. Immunopathology of inflammatory bowel disease. In: MacDermott RP, Stenson WF, eds. Inflammatory Bowel Disease. New York: Elsevier Science Publishers BV, 1992:95-136.

37. Helgeland L, Tysk C, Jarnerot G, et al. $\mathrm{IgG}$ subclass distribution in serum and rectal mucosa of monozygotic twins with or without inflammatory bowel disease. Gut 1992;33:1358-64.

38. Snook J. Are the inflammatory bowel diseases autoimmune disorders? Gut 1990;31:961-3.

39. Das KM, Vecchi M, Sakamaki S. A shared and unique epitope(s) on human colon, skin, and biliary epithelium detected by a monoclonal antibody. Gastroenterology 1990;98:464-9.

40. Halstensen TS, Das KM, Brandtzaeg P. Epithelial deposits of immunoglobulin G1 and activated complement colocalise with the $\mathrm{Mr} 40 \mathrm{kD}$ putative autoantigen in ulcerative colitis. Gut 1993;34:650-7.

41. Das KM, Dasgupta A, Mandal A, Geng $\mathrm{X}$. Autoimmunity to cytoskeletal protein tropomyosin. J Immunol 1993;150:2487-93.

42. Mandal A, Dasgupta A, Jeffers L, et al. Autoantibodies in sclerosing cholangitis against a shared peptide in biliary and colon epithelium. Gastroenterology 1994;106:185-92.

43. Mayer L, Eisenhardt D. Lack of induction of suppressor $T$ cells by intestinal epithelial cells from patients with inflammatory bowel disease. J Clin Invest 1990;86:1255-60.

44. Hoang P, Crotty B, Dalton HR, Jewell DP. Epithelial cells bearing class II molecules stimulate allogenic human colonic intraepithelial lymphocytes. Gut 1992;33:1089-93.

45. Crotty B, Hoang P, Dalton HR, Jewell DP. Salicylates used in inflammatory bowel disease and colchicine impair interferon- $\gamma$ induced HLA-DR expression. Gut 1992;33:59-64.

46. Fiocchi C. Mucosal cellular immunity. In Targan SR, Shanahan F, eds. Immunology and Immunopathology of the Liver and Gastrointestinal Tract. New York, Tokyo: Igaku-Shoin, 1990:107-38. 
47. Fukushima K, Masuda T, Ohtani H, et al. Immunohistochemical characterization, distribution, and ultrastructure of lymphocytes bearing T-cell receptor $\gamma \delta$ in inflammatory bowel disease. Gastroenterology 1991;101:670-8.

48. Hoang P, Senju M, Lowes JR, Jewell DP. Phenotypic characterization of isolated intraepithelial lymphocytes in patients with ulcerative colitis and normal controls. Dig Dis Sci 1992;37:1725-8.

49. VanKerckhove C, Russell GJ, Deusch K, et al. Oligoclonality of human intestinal intraepithelial T cells. J Exp Med 1992;175:57-63.

50. Landau SB, Balk SP, Yang L, Burke SK, Blumberg RS. T-cell receptor (TCR) $\delta$ variable region utilization is altered in ulcerative colitis. Gastroenterology 1992;102:A650.

51. Lionetti P, Breese E, Braegger CP, Murch SH, Taylor J, MacDonald TT. T-cell activation can induce either mucosal destruction or adaptation in cultured human fetal small intestine. Gastroenterology 1993;105:373-81.

52. Qiao L, Schurmann G, Autschbach F, Wallich R, Meuer SC. Human intestinal mucosa alters $\mathrm{T}$-cell reactivities. Gastroenterology 1993;105:814-9.

53. Aisenberg J, Ebert EC, Mayer L. T-cell activation in human intestinal mucosa: the role of superantigens. Gastroenterology 1993;105:1421-30.

54. Posnett DN, Schmelkin I, Burton DA, August A, McGrath H, Mayer LF. T cell antigen receptor $\mathrm{V}$ gene usage. Increases in $\mathrm{V}_{\beta} 8+\mathrm{T}$ cells in Crohn's disease. J Clin Invest 1990;85:1770-6.

55. Spencer J, Choy MY, MacDonald TT. $T$ cell receptor $V_{\beta}$ expression by mucosal T cells. J Clin Pathol 1991;44:915-8.

56. Duchmann R, Strober W, Fiocchi C, James SP. TCR $V_{\beta} 2$ gene expression is selective in control but not in IBD lamina propria lymphocytes. Gastroenterology 1992;102:A617.

57. Paliard X, West SG, Lafferty JA, et al. Evidence for the effects of a superantigen in rheumatoid arthritis. Science 1991;253:325-9.

58. Sperber K, Ogata S, Sylvester C, et al. A novel human macrophage-derived intestinal mucin secretagogue: implications for the pathogenesis of inflammatory bowel disease. Gastroenterology 1993;104:1302-9.

59. Fox CC, Lichtenstein LM, Roche JK. Intestinal mast cell responses in idiopathic inflammatory bowel disease. Dig Dis Sci 1993;38:1105-12.

60. Martens MFWC, Huyben CMLC, Hendriks T. Collagen synthesis in fibroblasts from human colon: regulatory aspects and differences with skin fibroblasts. Gut 1992;33:1664-70.

61. Lee EY, Stenson WF, DeSchryverKecskemeti K. Thickening of muscularis mucosas in Crohn's disease. Modern Pathol 1991;4:87-90.

62. Vermillion DL, Huizinas JD, Riddell RH, Collins SM. Altered small intestinal smooth muscle function in Crohn's disease. Gastroenterology 1993; 104:1692-9.
63. Strong SA, Klein JS, West GA, Fiocchi C. Activation of intestinal mesenchymal cells by IL1 $\beta$ induces inflammatory cytokine and procollagen gene expression. Gastroenterology 1993;104:A784

64. Springer TA. Adhesion receptors of the immune system. Nature 1990;346:425-34.

65. Cronstein BC, Weissmann G. The adhesion molecules of inflammation. Arthritis Rheum 1993;36:147-57.

66. Greenfield SM, Hamblin A, Punchard NA, Thompson RPH. Expression of adhesion molecules on circulating leucocytes in patients with inflammatory bowel disease. Clin Sci 1992;83:221-6.

67. Malizia G, Calabrese A, Cottone M, et al. Expression of leukocyte adhesion molecules by mucosal mononuclear phagocytes in inflammatory bowel disease. Gastroenterology 1991;100:150-9.

68. Koizumi M, King N, Lobb R, Benjamin C, Podolsky DK. Expression of vascular adhesion molecules in inflammatory bowel disease. Gastroenterology 1992;103:840-7.

69. Ohtani H, Nakamura S, Watanabe Y, et al. Light and electron microscopic immunolocalization of endothelial leucocyte adhesion molecules-1 in inflammatory bowel disease. Virchows Arch A Pathol Anat Histopathol 1992;420:403-9.

70. Nakamura S, Ohtani H, Watanabe Y, et al. In situ expression of the cell adhesion molecules in inflammatory bowel disease. Lab Invest 1993;69:77-85.

71. Mishra L, Mishra BB, Harris M, Bayless TM, Muchmore AV. In vitro cell aggregation and cell adhesion molecules in Crohn's disease. Gastroenterology 1993;104:772-9.

72. Salmi M, Granfors K, MacDermott RP, Jalkanen S. Aberrant binding of lamina propria lymphocytes to vascular endothelium in inflammatory bowel disease. Gastroenterology 1994;106:596-605.

73. Podolsky DK, Lobb R, King N, et al. Attenuation of colitis in the cotton-top tamarin by anti-alpha 4 integrin monoclonal antibody. J Clin Invest 1993;92:372-80.

74. Oppenheim JJ, Neta R. Pathophysiological roles of cytokines in development, immunity, and inflammation. FASEB J 1994;8:158-62.

75. Ferraris L, Karmeli F, Eliakim R, Klein J, Fiocchi C, Rachmilewitz D. Intestinal epithelial cells contribute to the enhanced generation of platelet activating factor in ulcerative colitis. Gut 1993;34:665-8.

76. Shannon VR, Stenson WF, Holtzman MJ. Induction of epithelial arachidonate 12-lipoxygenase at active sites of inflammatory bowel disease. Am J Physiol 1993;264:G104-11.

77. Fiocchi C. Cytokines. In: MacDermott $\mathrm{RP}$, Stenson W, eds. Inflammatory Bowel Disease. New York: Elsevier Publishing Company, 1992:137-62.

78. Fiocchi C. Cytokines. In: Targan SR, Shanahan F, eds. Inflammatory Bowe
Disease. From Bench to Bedside. Baltimore: Williams \& Wilkins, 1994:106-22.

79. Sartor RB. Cytokines in intestinal inflammation: pathophysiological and clinical considerations. Gastroenterology 1994;106:533-9.

80. Fiocchi C, Podolsky DK. Cytokines and growth factors in inflammatory bowel disease. In: Kirsner JB, Shorter RG, eds. Inflammatory Bowel Disease. Malvern: Lea \& Febiger, 1995:252-80.

81. Sparano JA, Brandt LJ, Dutcher JP, DuBois JS, Atkins MB. Symptomatic exacerbation of Crohn's disease after treatment with high-dose interleukin-2. Ann Intern Med 1993;118:617-8.

82. James SP. Remission of Crohn's disease after human immunodeficiency virus infection. Gastroenterology 1988;95:1667-9.

83. Matsuura T, West GA, Klein JS, et al. Immune activation gene products are resistant to IL4 inhibitory activity in Crohn's disease (CD). Gastroenterology 1993;194:A739.

84. Mullin GE, Lazenby AJ, Harris ML, Bayless TM, James SP. Increased interleukin-2 messenger RNA in the intestinal mucosal lesions of Crohn's disease but not ulcerative colitis. Gastroenterology 1992;102:1620-7.

85. Matsuura T, West GA, Klein JS, Ferraris L, Fiocchi C. Soluble interleukin 2, CD8 and CD4 receptors in inflammatory bowel disease. A comparative study of peripheral blood and intestinal mucosal levels. Gastroenterology 1992;102:2006-14.

86. Arend WP. Interleukin-1 receptor antagonism. J Clin Invest 1991;88:1445-51.

87. Casini-Raggi V, Kam L, Jin Y, Fiocchi C, Pizarro TT, Cominelli F. Mucosal imbalance of interleukin-1 and interleukin-1 receptor antagonist in inflammatory bowel disease: a novel mechanism of chronic intestinal inflammation. J Immunol 1995; 154:2434-40.

88. Mansfield JC, Holden H, Tarlow JK, et al. Novel genetic association between ulcerative colitis and the anti-inflammatory cytokine interleukin-1 receptor antagonist. Gastroenterology 1994;106:637-42.

89. Hymas JS, Treem WR, Eddy E, Wyzga N, Moore RE. Tumor necrosis factor- $\alpha$ is not elevated in children with inflammatory bowel disease. J Pediatr Gastroenterol Nutr 1991;12:233-6.

90. Tan X, Hsueh W, Gonzales-Crussi F. Cellular localization of tumor necrosis factor (TNF) $-\alpha$ transcripts in normal bowel and in necrotizing enterocolitis. Am J Pathol 1993;142:1858-65.

91. Izzo RS, Witkon K, Chen AI, Hadjiyane C, Weinstein MI, Pellecchia C. Interleukin- 8 and neutrophil markers in colonic mucosa from patients with ulcerative colitis. Am J Gastroenterol 1992;87:1447-52.

92. Izzo RS, Witkon K, Chen AI, Hadjiyane C, Weinstein MI, Pellecchia C. Neutrophil-activating peptide (interleukin-8) in colonic mucosa from 
patients with Crohn's disease. Scand J Gastroenterol 1993;28:269-300.

93. Mahida YR, Ceska M, Effenberger F, Kurlak L, Lindley I, Hawkey CJ. Enhanced synthesis of neutrophil-activating peptide-1/ interleukin-8 in active ulcerative colitis. Clin Sci 1992;82:273-5.

94. Eckmann L, Jung HC, Schurer-Maly C, Panja A, Morzycka-Wroblewska E, Kagnoff MF. Differential cytokine expression by human intestinal epithelial cell lines: regulated expression of interleukin 8. Gastroenterology 1994:105:1689-97.

95. Zimmermann EM, Sartor RB, McCall RD, Pardo M, Bender D, Lund PK. Insulin growth factor I and interleukin $1 \beta$ messenger RNA in a rat model of granulomatous enterocolitis and hepatitis. Gastroenterology 1993:105:399-409.

96. Wright NA, Poulsom R, Stamp G, et al. Trefoil peptide gene expression in gastrointestinal epithelial cells in inflammatory bowel disease.

Gastroenterology 1993;194:12-20.

97. Ohtani H, Nakamura S, Watanabe Y, Mizoi T, Saku T, Nagura H. Immunocytochemical localization of basic fibroblast growth factor in carcinomas and inflammatory lesions of the human digestive tract. Lab Invest 1993;68:520-7.

98. Ciacci C, Lind SE, Podolsky DK. Transforming growth factor $\beta$ regulation of migration in wounded rat intestinal epithelial monolayers. Gastroenterology 1993;105:93-101.

99. Dignass AU, Podolsky DK. Cytokine modulation of intestinal epithelial cell restitution: central role of transforming growth factor $\beta$. Gastroenterology 1993;105:1323-32.

100. Goetzel EJ, Sreedharan SP. Mediators of communication and adaptation in the neuroendocrine and immune systems. FASEB J 1992;6:2646-52.

101. Sternberg EM, Chrousos GP, Wilder RL, Gold PW. The stress response and the regulation of inflammatory disease. Ann Intern Med 1992;117:854-66.

102. Geboes K, Rutgeerts P, Ectors N, et al. Major histocompatibility class II expression on the small intestinal nervous system in Crohn's disease.

Gastroenterology 1992;103:439-47.

103. Boirivant M, Fais S, Annibale B, Agostini D, Fave GD, Pallone F. Vasoactive intestinal polypeptide modulates the in vitro immunoglobulin A production by intestinal lamina propria lymphocytes. Gastroenterology 1994;106:576-82.

104. Lloyd AR, Hoppenheim JJ. Poly's lament: the neglected role of the polymorphonuclear neutrophil in the afferent limb of the immune response. Immunol Today 1992;13:169-72.

105. Simmonds NJ, Rampton DS. Inflammatory bowel disease - a radical view. Gut 1993;34:865-8.

106. Oshitani N, Kitano A, Okabe H, Nakamura S, Matsumoto T, Kobayashi K. Location of superoxide anion generation in human colonic mucosa obtained by biopsy. Gut 1993;34:936-8.

107. Baldassano RN, Schreiber S, Johnston RB, Fu RD, Muraki T, MacDermott RP. Crohn's disease monocytes are primed for accentuated release of toxic oxygen metabolites. Gastroenterology 1993;105:60-6.

108. Bilotta JJ, Waye JD. Hydrogen peroxide enteritis: the "Snow White" sign. Gastrointest Endosc 1989;35:428-30.

109. Tamai H, Levin S, Gaginella TS. Induction of colitis in rats by $2\lceil-2\lceil$-azobis (2-amidinopropane) dihydrochloride. Inflammation 1992;16:69-81.

110. Williams JP. Phagocytes, toxic oxygen metabolites and inflammatory bowel disease: implications for treatment. Ann R Coll Surg Engl 1990;72:253-62.

111. Rudra T, Motley RJ, Rhodes J. Does smoking improve colitis? Scand J Gastroenterol 1989;170(Suppl):61-3.

112. Cottone M, Rosselli M, Orlando A, et al. Smoking habits and recurrence of Crohn's disease. Gastroenterology 1994;106:643-8.

113. Rhodes J, Thomas GAO. Smoking: good or bad for inflammatory bowel disease? Gastroenterology 1994;106:807-10.

114. Pullman RD, Rhodes J, Ganesh S, et al. Transdermal nicotine for active ulcerative colitis. N Engl J Med 1994;330:811-5.

115. Katz KD, Hollander D, Vadheim CM, et al. Intestinal permeability in patients with Crohn's disease and their healthy relatives. Gastroenterology 1989;97:927-31

116. Teahon K, Smethurst P, Levi AJ, Menzies IS, Bjarnason I. Intestinal permeability in patients with Crohn's disease and their first degree relatives. Gut 1992;33:320-3.

117. Adenis A, Colombel J-F, Lecouffe P, et al. Increased pulmonary and intestinal permeability in Crohn's disease. Gut 1992;33:678-82.

118. Hollander D. Permeability in Crohn's disease: altered barrier function in healthy relatives? Gastroenterology 1993;1993:1848-73.

119. May GR, Sutherland LR, Meddings JB. Is small intestinal permeability really increased in relatives of patients with Crohn's disease? Gastroenterology 1993;104:1627-32.

120. Jewell DP, Campieri M, Jarnerot $G$, Modigliani R, Rask-Madsen J. New therapeutic modalities for inflammatory bowel disease. Gastroenterol Int 1993;6:1-12

121. Hawkey CJ, Mahida YR, Hawthorne AB. Therapeutic interventions in gastrointestinal disease based on an understanding of inflammatory mediators. Agents Actions 1992:C22-5.

122. Stenson WF, Cort D, Rodgers J, et al. Dietary supplementation with fish oil in ulcerative colitis. Ann Intern Med 1992;116:609-14.

123. Sutherland LR, May GR, Shaffer EA. Sulfasalazine revisited: a meta-analysis of 5 -aminosalicylic acid in the treatment of ulcerative colitis. Ann Intern Med 1993;118:540-9.

124. Sandborn WJ, Tremaine WJ Cyclosporine treatment of inflammatory bowel disease. Mayo Clin Proc 1992;67:981-90

125. Scheppach W, Sommer H, Kirchner T, et al. Effect of butyrate enemas on the colonic mucosa in distal ulcerative colitis. Gastroenterology 1992;103:51-6.

126. Breuer RI, Buto SK, Christ ML, et al. Rectal irrigation with short-chain fatty acids for distal ulcerative colitis. Dig Dis Sci 1991;36:185-7.

127. Roediger WEW. The colonic epithelium in ulcerative colitis: an energy-deficiency disease? Lancet 1980;ii:712-5. 


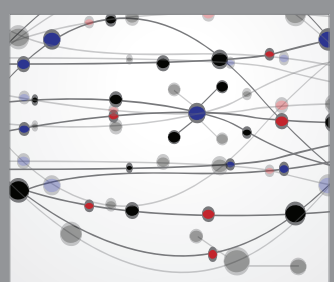

The Scientific World Journal
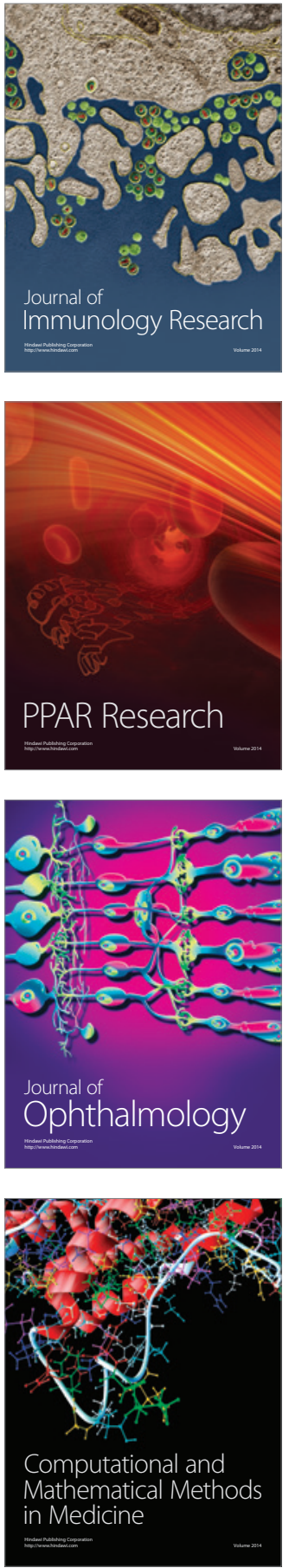

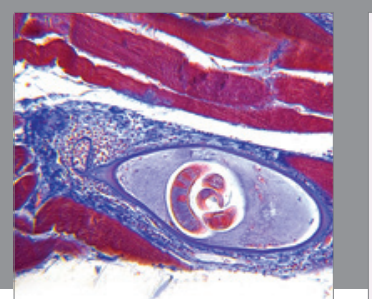

Gastroenterology Research and Practice

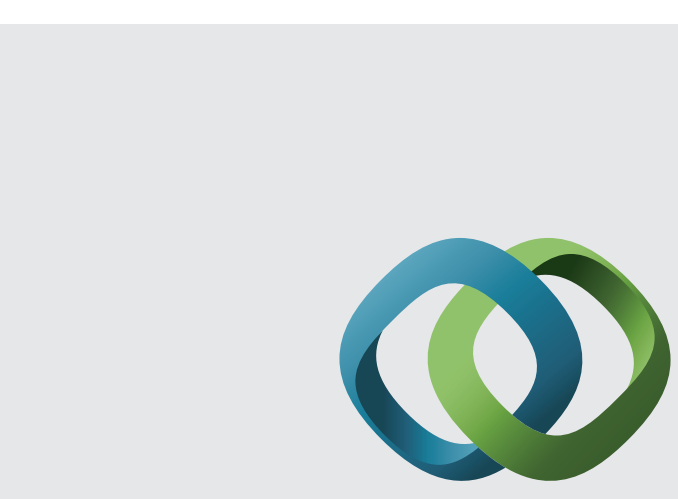

\section{Hindawi}

Submit your manuscripts at

http://www.hindawi.com
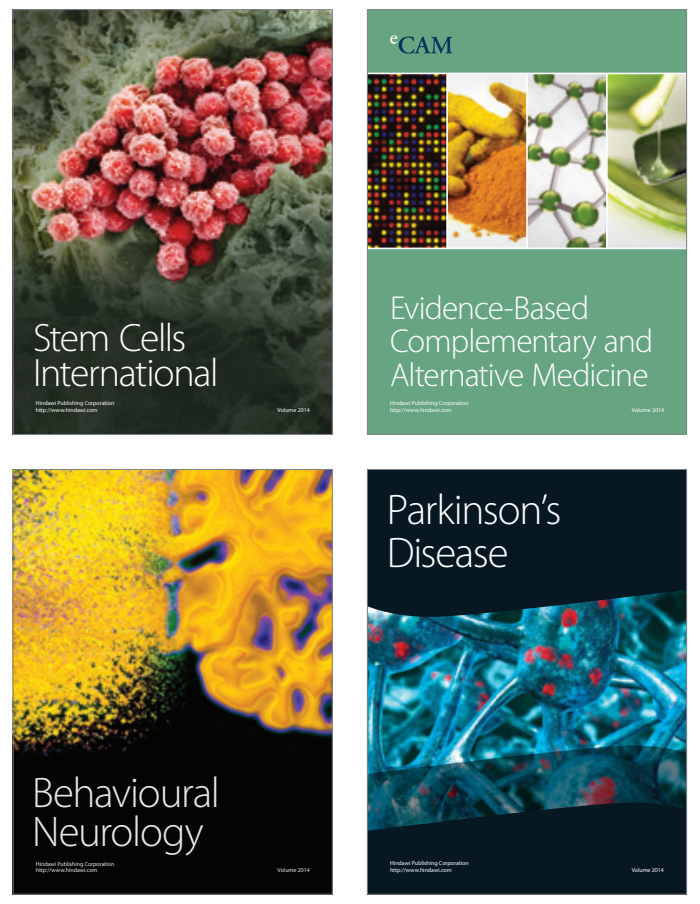
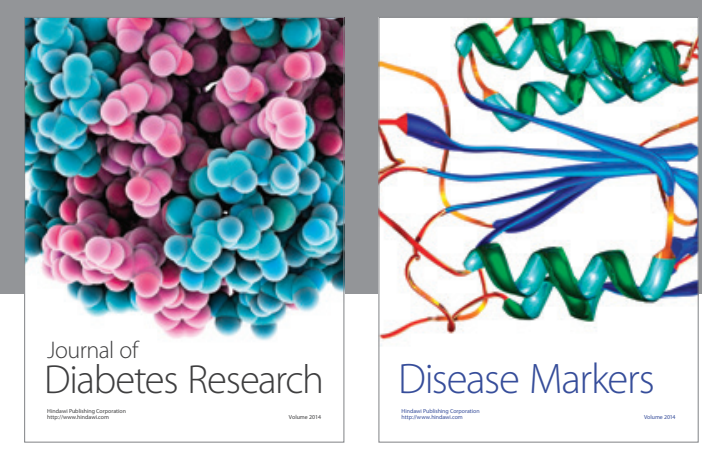

Disease Markers
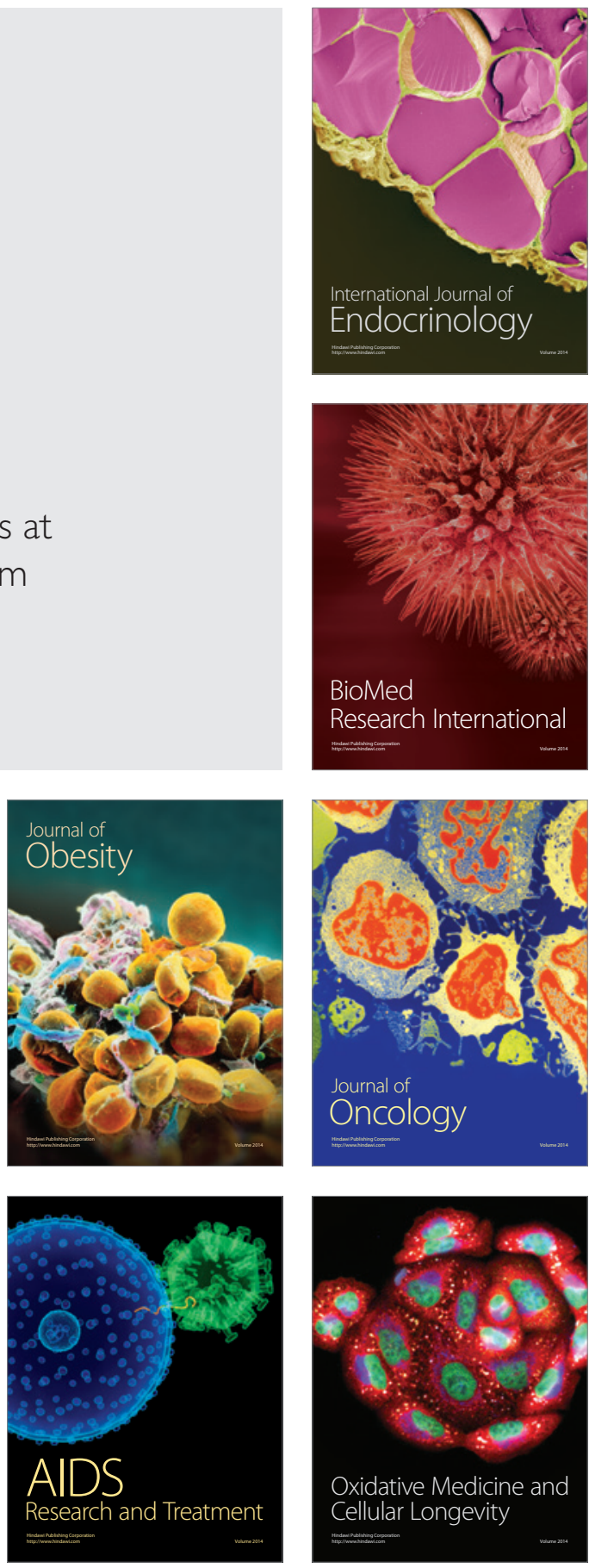